\title{
GOFFREDO TELLES JÚNIOR: A POESIA DO DIREITO
}

\author{
Guilherme Assis de Almeida \\ Professor Doutor do Departamento de Filosofia e Teoria Geral do \\ Direito da Faculdade de Direito da Universidade de São Paulo
}

1.

"Este páteo de pedra é o jardim dos meus sonhos"

Acredito que esta singela frase é a precisa síntese do pensamento jurídico de Goffredo Telles Júnior.

O páteo, a que Goffredo faz referência, é o páteo das Arcadas, aqui que Goffredo desenvolveu todo sua carreira intelectual, nunca como Professor, mas sempre como aluno' Esta postura existencial e intelectual está incorporada no modo de vida de Goffredo, assim não é por acaso que sua obra autobiográfica tem como subtítulo "Memórias de um Estudante"

2.

Seu mais recente livro "Iniciação na Ciência do Direito"2 representa a essência de tudo o que Goffredo pensa sobre o Direito, atrevo-me a dizer que esta obra é seu testamento jurídico-poético, nela Goffredo explicita o modo, através do qual enxerga o Direito e convida o leitor a compartilhar deste olhar. Goffredo sabe e a física quântica prova cientificamente que todo fenômeno material transforma-se de acordo com a perspectiva do observador. ${ }^{3}$

Para Goffredo o Direito não é uma mera Ciência, mas uma Ciência poética. Poesia enquanto arte do possível que se diferencia do real. Assim o Direito

1. "Uma vez aluno nunca mais cx-aluno, mais scmpre antigo aluno" ć a frase que Goffredo costuma dizer para scus colegas

2. Trata-sc do livro: TELlES JR., Goffredo Iniciação na Ciência do Direito. São Paulo: Saraiva, 2001 .

3. Para comprecnder csta asscrtiva da fisica quântica, consultc GOSWAMI, Amit c GOSWAMI, Maggic c REED, Richard E. O Universo Autoconsciente como a conscichncia cria o mundo matcrial. Rio de Janciro: Editora Rosa dos Tempos, 1998. 
parte do real mas almeja o possivel ${ }^{4}$ O possivel é sempre melhor do que o real, é o que potencialmente podemos atingir, ainda não é realidade presente, mas perspectiva futura.

No dia 11 de agosto de 1977, Goffredo tornou de conhecimento público, no lotado páteo das Arcadas, a "Carta aos Brasileiros" esta representou, sem a menor sombra de dúvida, o primeiro ato juspoético da História Política brasileira.

3.

Em 1977, estávamos em plena Ditadura Militar. Recapitulando os principais fatos deste período: outubro de 1975 o jornalista Vladimir Herzog foi assassinado pelas forças da repressão, janeiro de 1976 foi a vez de Manuel Fiel Filho, do Sindicato dos Metalúrgicos, abril de 1977, o presidente Ernesto Geisel decreta o "Pacote de Abril" fechando o Congresso Nacional.

É nesse estado de coisas que Goffredo leu a "Carta aos Brasileiros", exigindo o imediato retorno do Estado de Direito. De acordo com as próprias palavras de Goffredo a "Carta aos Brasileiros" foi considerada dentro da "massa de manobra" da Ditadura Militar, isto ocorreu porque a "Carta" não é um manifesto político, mas um texto juspoético.

Explica Olavo de Carvalho que a poesia tem credibilidade pela sua magia e "faz o ouvinte participar de um mundo de percepções, evocações, sentimentos, de modo que, não existindo hiato entre o poeta e seu público, a comunhão espiritual e contemplativa - de vivências é como se a própria vida falasse."

A "Carta aos Brasileiros" cumpriu sua missão, o público ouvinte imergiu numa aura poética que reacendeu as esperanças do retorno da democracia.

4.

A "Carta aos Brasileiros" é a mais marcante aparição pública da Poesia do Direito e a "Iniciação na Ciência do Direito" um marco deste "velho e sempre novo" ramo do Direito.

Por iniciação devemos entender:

“A palavra iniciação é uma palavra carregada de sentido. Eu a emprego pensando no que dizia Políbio, quando apontou que em todo assunto a

\footnotetext{
4. Nunca é demais Iembrar este pátco de pedra é o jardim de meus sonhos...

5. CARVALHO, Olavo de Aristóteles em Nova Perspectiva Rio de Janciro: Topbooks Editora, 1996,
} p. 49 
principal preocupação devia ser a de bem começar. Por esta razão, afirmava Políbio, o começo não é apenas a metade do todo, mas entranha-se no fim (Políbio, História, V, 32). É a hierarquia da Ética, da Justiça e da Liberdade a lição que o professor Goffredo soube inserir e entranhar na sensibilidade das sucessivas gerações dos seus alunos."

A organização dos capítulos de "Iniciação na Ciência do Direito" é um convite a compartilhar o pensamento juspoético de Goffredo. O livro divide-se em cinco partes: 1. A ordem e a desordem. As normas e a normalidade; 2 . A norma jurídica: o Direito objetivo; 3. o Direito subjetivo; 4. a Justiça; 5. a definição do Direito. Na sua iniciação Goffredo apresenta o Direito (objetivo e subjetivo) e o recheia de poesia ao ligálo, de modo imprescindivel, a Justiça, na última parte o autor explicita sua definição pessoal.

Goffredo esclarece que a palavra Direito possui três significados: 1 . como imperativo autorizante (Direito objetivo); 2. enquanto permissão concedida por meio de norma jurídica (Direito subjetivo); 3 . designando uma qualidade especial o justo segundo a lei.

Goffredo é um excelente orientador, não deixa dúvidas para seus alunos, o Direito e o justo estão essencialmente ligados. O sentido do justo será encontrado no exercício da interpretação.

"Miguel Reale escreveu: "Uma norma é sua interpretação" Impossível dizer melhor ( Filosofia do Direito, 5a ed., Parte II, Título X, Capítulo XXXVIII, n. 124)."”

Goffredo mostra como deve ser feita a interpretação:

"Mas é evidente que a interpretação há de ser correta. Há de ser uma interpretação de jurista, ou seja, uma interpretação preocupada com a intenção e o espírito da lei, que nem sempre coincide com o estricto sentido literal da mesma." 8

"A verdadeira compreensão das leis, a sábia interpretação delas, a sua aplicação prudente ao caso concreto, não depende de erudição apenas, mas de sabedoria, "not knowledge, but Wisdow", daquela "sabedoria profunda e silenciosa, de que falam os pensadores.

Valendo-se da lógica do razoável, o juiz fará uma Justiça que "excede

6. LAFER, Celso “A Folha Dobrada de Goffredo Telles Júnior” cm Revista da Faculdade de Direito, v. 95 , pp. 46 I c 462 .

7. TELLES JR., Goffredo “Iniciação na Ciência do Dircito". São Paulo: Saraiva, 2001. p. 366.

8. TELLES JR., Goffredo obra citada. p. 367. 
a justiça dos escribas e dos fariseus" a que se referiu Jesus, no "Sermão da Montanha."

5.

No último capítulo, Goffredo reafirma sua conhecida definição do Direito, enquanto disciplina da convivência humana:

"Mas, para a ordem na comunidade, o Direito é a disciplina da convivência por excelência. É importantíssima. Dela depende o reino efetivo do bem comum e o empenho da Justiça no entrechoque dos interesses. Dela dependem as garantias do respeito pelo próximo, ou seja, do respeito de cada um pelas pessoas e pelos direitos dos outros, assim como do respeito dos outros pela pessoa e pelos direitos de cada um. Dela depende a correlação impositiva entre direitos e deveres."

Imprescindivel atentar para o fato que no pensamento de Goffredo, quando não-existe convivência, o Direito perde sua razão de ser, pois já não tem sobre o que se debruçar. Nos sombrios tempos atuais, que Hobsbawn caracteriza como a época do "individualismo associal" O Direito corre perigo...

Teilhard de Chardin diz que a Humanidade sofrerá uma transformação equivalente a descoberta do fogo, quando descobrirmos a energia do amor. Goffredo sabe disso, e tem plena consciência de que esta é a forma de zelar pela continuidade da disciplina da convivência humana:

"O amor pelo próximo é princípio subliminar da ordem. É o sentimento primeiríssimo, o primeiríssimo elã da alma, dos que são levados a conviver numa comunidade. Mesmo quando obumbrado, não bem percebido ou expresso, ele é o cimento subjacente da união dos seres na sociedade. É o elo tácito da comunhão humana

Em verdade, o amor constitui, no imo da consciência de legisladores e intérpretes, a matriz silenciosa, o submerso manancial, a inspiração geradora da disciplina da convivência. É a origem mais pura, mais profunda da legislação: a causa das suas causas.

É a fonte natural do Direito."

6.

A poesia do Direito de Goffredo por se localizar no terreno do possível ao invés do real, não é de fácil compreensão. Goffredo, em essência, é um poetaprofeta que antecipa o porvir.

9. TELLES JR., Goffredo obra citada. p. 367.

10. TELLES JR., Goffredo obra citada. p. 381

I1. TELLES JR., Goffredo obra citada. p. 384 
Como canta, outro grande poeta de nossa terra, Caetano Emanuel da Silva Telles Veloso :

$$
\text { (...) }
$$

Do objeto sim resplandecente

Descerá o índio

$E$ as coisas que eu sei que ele

dirá, fará

Não sei assim dizer de um modo

$$
\text { explícito }
$$

$$
\begin{aligned}
& \text { Virá (...) } \\
& \text { E aquilo que nesse momento se } \\
& \text { revelará aos povos } \\
& \text { Surpreenderá a todos não por } \\
& \text { ser exótico } \\
& \text { Mas pelo fato de poder ter } \\
& \text { sempre estado oculto } \\
& \text { Quando terá sido o óbvio }
\end{aligned}
$$

São Paulo, maio de 2001.

12. VELOSO, Cactano Um Indio. História da Música Popular Brasileira Grandes Compositores. São Paulo: Abril S.A. Cultural c Industrial, 1982. I Long Play (42 min; 40 seg): cstćrco. 61373494. Lado B. faixa I. 